Research Article

\title{
Preparation and Characterization of A Co-Processed Excipient from Purple Sweet Potato (Ipomoea batatas L) Starch and Avicel PH101
}

\author{
Muhammad Hengki Purnama Halim*, Ungsari Rizki Eka Purwanto, Endang Diyah Ikasari \\ Sekolah Tinggi Ilmu Farmasi Yayasan Pharmasi Semarang, Indonesia \\ *Corresponding author: Muhammad Hengki Purnama Halim I Email: hengkipurnama0315@gmail.com \\ Received: 11 November 2020; Revised: 16 December 2020; Accepted: 29 December 2020; Published: 31 December 2020
}

\begin{abstract}
The Indonesian pharmaceutical industries still rely on imports for more $90 \%$ of active raw materials and excipient raw materials. A research is needed to develop the production of pharmaceutical excipients, especially those derived from natural ingredients, to support the country's economy. One source of natural materials are widely available in Indonesia and can be developed is starch from Purple Sweet Potato (Ipomoea batatas L). Starch is often used as dilluent, disintegrat and binder in tablet formulation. Starch, including starch from Purple Sweet Potato, was an excipient tablet that had bad flowability and compressibility, so that the physical properties need to be improved. One way to improve the characterization of amilum is co-processing. The purpose of this study was to develop a co-process from Purple Sweet Potato Starch and combined with Avicel PH 101 as excipient fillers for tablets. The method used in the preparation of these co-process was wet granulation. The formula determination was caried out with Design Expert 10.0.1 software. Results obtained from experiments and recommendation formula from Design Expert 10.0.1 was verified with One Simple Ttest with confidence level of $95 \%$. The results showed that the increased concentration of purple sweet potato starch increased moisture content and lowering compressibility and density. While the increased concentration of Avicel PH 101 increased compressibility and density; it could lower moisture content and the flowability time. The formula that gave the best characteristic of co- processed was obtained at a concentration of purple sweet potato starch and Avicel PH 101 on 62.493\%: 37.507\%. Based on One Simple T-Test, there is no significant difference between the experimental results with recommendation formula from Design Expert 10.0.1. From the FT-IR test results may indicate that the formation of the co-process did not change the form of the chemical structure of substances, but only changed the physical properties of substance. Based on the results of SEM, the morphology of the shape bond formation co- process so that the granules become larger and purple sweet potato starch forms a round and partly change shape after do the heating at $60^{\circ} \mathrm{C}$.
\end{abstract}

Keywords : Co-processing, Purple Sweet Potato, Starch, Avicel PH101, FTIR

\section{INTRODUCTION}

Purple sweet potato starch had long been used to be produced in various region in Indonesia, but only a small portion was produced with pharmaceutical grade quality [1]. Based on functional amd price reasoning we can expand Indonesian natural ingredients in the form of purple sweet potato starch as an excipient. As we know that Indonesian pharmaceutical industries still rely on imports for more $90 \%$ of active raw materials and excipient raw materials [2,3]. A research is needed to develop 
the production of pharmaceutical excipients. Starch from purple sweet potato can be the one of solution for it.

However, starch, including starch from Purple Sweet potato starch had bad flowability and compressibility, so that the physical properties need to be improved [4]. Co-processing is a technique for obtaining new excipients by combining two or more existing excipients. The combination of materials chosen will complement each other so that new materials will be obtained with the desired properties. New materials resulting from co-processing are commonly referred to as co-process excipients [5]. Co-processed creates the possibility to improve the characteristics of purple sweet potato starch.

One of the excipients that can be used for the combination of starch into a co-process was Avicel PH 101. Avicel PH 101 is a microcrystalline cellulose (MCC) in the form of a white powder, insoluble in water, non-reactive, free flowing and a filler that is good. It can improve the flow properties of purple sweet potato starch [6]. This study aims to determine and develop co-process granules from purple sweet potato starch and avicel PH 101 as a filler for tablets and improve the flow properties of purple sweet potato starch.

\section{MATERIAL AND METHODS}

\subsection{Purple sweet potato starch isolation}

The isolation of purple sweet potato starch was carried out by peeling and washing the purple sweet potato, then cutting it, blending it with the addition of aquadest: citric acid (9:1). After 24 hours, the precipitate (starch) formed was dried. Dry starch was mashed and sieved using mesh No. 60.

\subsection{Preparation of starch paste}

The binder in the co-processed formula was purple sweet potato starch at $10 \%$ of the total weight made, and this would subtract the proportion of purple sweet potato starch that was granulated with avicel PH 101. Co-processed was made up to 200 grams in each formula, so the binder required was 20 grams. The purple sweet potato starch was added with $100 \mathrm{~mL}$ hot aquadest and stirred until it expanded into a paste.

Table 1. The Composition Comparison of Purple Sweet Potato Starch with Avicel PH 101 in Each CoProcessed Formula

\begin{tabular}{ccc}
\hline \multirow{2}{*}{ Formula } & Component 1 & Component 2 \\
\cline { 2 - 3 } 1 & A : Avicel PH 101 & B : Purple Sweet Potato Starch \\
\cline { 2 - 3 } 2 & 25 & 75 \\
3 & 25 & 75 \\
4 & 37,5 & 62,5 \\
5 & 50 & 50 \\
6 & 50 & 50 \\
7 & 62,5 & 37,5 \\
8 & 75 & 25 \\
\hline
\end{tabular}

\subsection{Preparation of co-processed from purple sweet potato starch - Avicel PH 101 (PA)}

Co-processing was carried out by referring to the method of Gohel and Jogani 2003 [5]. The proportions of sweet potato starch and avicel PH 101 were formulated using Design Expert 10.0.1. 
software in order to obtain the composition ratio that produces the best co-processing characteristics. Purple sweet potato starch and avicel PH 101 with a comparative ratio (Table 1) were put into a porcelain mortar, mashed and homogenized. After that it was granulated with purple sweet potato starch paste then sieved with a mesh sieve no. 60 . The co-process that was formed was dried in a drying cabinet at $60^{\circ} \mathrm{C}$ for 3 hours and then it was evaluated for characteristic properties, such as moisture content, compressibility, flowability time and density.

\subsection{Physical characteristic test of co-processed PA}

\subsubsection{Moisture content}

The moisture content of the co-processed was measured using a moisture tester. 5 grams of co-processed put in a moisture tester, it was measured at a temperature of $80^{\circ} \mathrm{C}$ for 15 minutes.

\subsubsection{Compressibility}

This test was done by weighing 50 grams of co-processed, inserted into the tube on the powder taping density tester. The co-processed volume in the tube were recorded before and after the stamping. This test was performed three times and calculated the price of compressibility (\%) by the Carr equation.

\subsubsection{Flowability time}

100 grams of co-processed are put into the funnel in flowmeter which was closed at the bottom of the funnel. The lid at bottom of the funnel was then opened and the co- processed was allowed to flow out. The time from the start of co-processed flow to all flows was recorded.

\subsubsection{Density}

The true density $(\rho)$ was carried out using a pycnometer. Empty pycnometer with known volume (a) is weighed (b), then filled with paraffin and weighed (c), the density of paraffin could be calculated by the equation 1 .

$$
\rho=\frac{\mathrm{c}-\mathrm{b}}{\mathrm{a}}
$$

Next, put 1 gram of co-processed into the pycnometer and weigh it (d), then add paraffin to it until about half, then cover and leave for 15 minutes while shaking. After adding paraffin to full pycnometer, cover and weigh (e). True density $(\rho)$ is calculated by the equation 2 .

$$
\text { True } \rho=\frac{\mathrm{d}-\mathrm{b}}{(d-b)+(c-e)} x \rho
$$

\section{RESULT AND DISCUSSION}

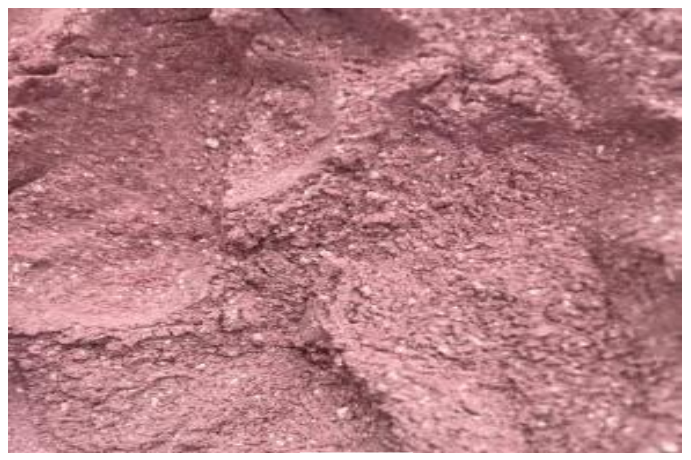

A

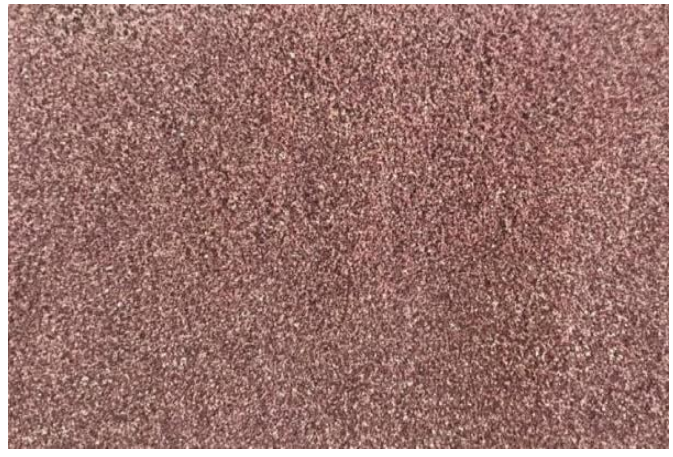

B

Figure 1. (A) Purple Sweet Potato Starch; (B) Co-processed Purple Sweet Potato Starch-Avicel PH101 $(\mathrm{PA})$ 
The yield of purple sweet potato starch isolation was $8.5 \%$. Macroscopic identification was obtained by a fine powder, sometimes there are small lumps, purple, odorless and tasteless. Meanwhile, microscopically, the results were single grain, slightly rounded, the point hilum in the middle (Fig.1). The results of this identification had the same identification as the compendial Indonesian Pharmacopoeia [7]. The 100 grams of starch could be flow in 40 second and had the compresibility of $31,27 \%$. The starch obtained was purple powder. This was because citric acid as a solvent combination during starch isolation could attract anthocyanins (dyes) from purple sweet potato.

The mixture of purple sweet potato starch and avicel PH 101 was granulated with starch paste and then sieved with a sieve no 44/60. The co-process formed was dried in a drying cabinet with a temperature of $60 \mathrm{oC}$ for 3 hours. The dry co-process was put into the container. The coprocessed formed in each formula was evaluated for several characteristic properties, such as moisture content, compressibility, flowability time, and density (Table 2).

Table 2. The response of Co-Processed Purple Sweet Potato-Avicel PH 101 (PA) Characteristic Test Results

\begin{tabular}{ccccc}
\hline Formula & $\begin{array}{c}\text { Moisture } \\
\text { Content (\%) }\end{array}$ & $\begin{array}{c}\text { Compresibility } \\
\mathbf{( \% )}\end{array}$ & $\begin{array}{c}\text { Flowability } \\
\text { Time } \\
(\mathbf{s e c o n d})\end{array}$ & $\begin{array}{c}\text { Density } \\
(\mathbf{g} / \mathbf{m L})\end{array}$ \\
\hline $\mathbf{1}$ & 7.32 & 15.99 & 4.9 & 1.2402 \\
$\mathbf{2}$ & 6.93 & 16.00 & 4.6 & 1.4038 \\
$\mathbf{3}$ & 5.58 & 17.01 & 4.3 & 1.4622 \\
$\mathbf{4}$ & 4.33 & 17.99 & 4.6 & 1.5135 \\
$\mathbf{5}$ & 4.42 & 18.99 & 4.8 & 1.5319 \\
$\mathbf{6}$ & 4.03 & 19.99 & 4.0 & 1.5694 \\
$\mathbf{7}$ & 3.65 & 21.99 & 3.8 & 1.5870 \\
$\mathbf{8}$ & 3.83 & 20.03 & 3.9 & 1.6377 \\
\hline
\end{tabular}

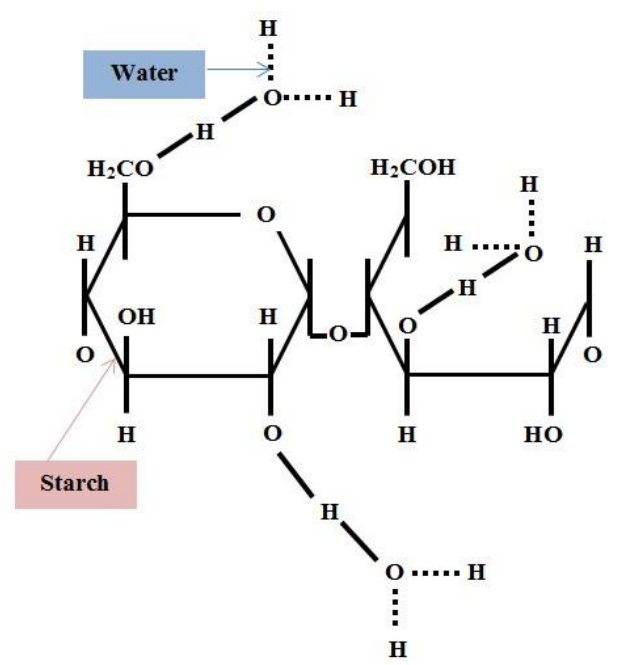

Figure 2. Hydrogen Bonding of Water to Starch [9] 
The data showed that the higher avicel PH 101 concentration reduced the moisture content, on the contrary the higher concentration of purple sweet potato starch caused increasing the moisture content. The requirement of moisture content was 3-5\%[8]. High moisture content would cause low flowability (the flowability time was more longer). This was causes when the co-process granules were made using a starch binder which was formed into a paste (starch that is bound to water molecules: (Fig. 2) [9]. Testing of moisture content in co-processed aimed to determine the water content in co-processed because water could affect the length of storage granules. When the moisture was higher, it would be easier the microbial contamination in preparation during storage.

Compressibility is a trait to form a stable and compact mass when pressed. All the formula fulfilled the compresibility requirement (less than 20\%), except the 8th and 9th formula. When the purple sweet potato starch was higher, the compresibility of the co- processed would be lower. It was because the binder that used in co-processed was also starch that expanded into a paste. This would make the co-processed was more compact and gave cohesiveness. The granules from coprocessed will be grown through the nucleation stage of starch paste with purple sweet potato starch and avicel PH 101 [10].

The flowability time represented the amount of time required by some co-processed to flow through the funnel on the flowmeter. Evaluation of co-processed flow time had done. The aim of this evaluation was to find out whether the co-processed contain purple sweet potato starch and avicel could fulfill the requirements so it was expected to produce free-flowing co-processed. All the formulas fulfilled requirement (less than 10 second). Flow time was closely related to moisture content. When the composition of purple sweet potato starch was higher, the moisture content would also be high and affected the ability of the co- processed material to flow.

The practical results of each test parameter are compared to the theoretical results. The data showed that the practical and theoretical results were not significantly different (significance value $>0.05$ ) so that the equation for each test parameter response and the best formula from Design Expert was valid.

Table 3. Results of functional group interpretation with FTIR

\begin{tabular}{|c|c|c|c|c|}
\hline \multirow[b]{2}{*}{$\begin{array}{c}\text { Fungctional } \\
\text { Group }\end{array}$} & \multicolumn{4}{|c|}{ Wave number $(\mathrm{cm}$ - } \\
\hline & $\begin{array}{c}\text { Standar } \\
\text { (Williams } \\
\text { \& Fleming, 2013) }\end{array}$ & $\begin{array}{c}\text { Avicel PH } \\
101\end{array}$ & $\begin{array}{c}\text { Starch Sweet } \\
\text { Purple } \\
\text { Potato }\end{array}$ & $\begin{array}{c}\mathrm{Co}^{-} \\
\text {processed } \\
\text { PA }\end{array}$ \\
\hline O-H Stretching & $3600-3200$ & $3288 ; 3332$ & $3265 ; 3247$ & 3280 \\
\hline C-H Stretching & $2890-2880$ & 2896 & - & 2904 \\
\hline $\begin{array}{l}\text { C-H2 Bending } \\
\text { C-H Bending }\end{array}$ & $1470-1430$ & $1457 ; 1420$ & $\begin{array}{c}142 \\
n\end{array}$ & 1420 \\
\hline C-O-C Stretching & $1170-1050$ & $\begin{array}{c}1159 ; 1103 ; \\
1151\end{array}$ & $1103 ; 1077$ & $\begin{array}{r}1103 ; \\
1073\end{array}$ \\
\hline C-O Stretching & $1060-1035$ & 1029 & - & - \\
\hline
\end{tabular}

According to Yugatama et al, (2015) in avicel PH 101 there are various groups, namely: O-H stretching, C-H stretching, $\mathrm{C}-\mathrm{H}_{2}$ bending, $\mathrm{C}-\mathrm{H}$ bending, $\mathrm{C}-\mathrm{O}-\mathrm{C}$ stretching, and $\mathrm{C}-\mathrm{O}$ stretching [11]. FT-IR result showed that the co-process PA contains functional groups found in Avicel PH 101 
and purple sweet potato starch. It could also be seen in Fig.3, overlay results between Avicel PH 101, purple sweet potato starch and co-process PA where the co-process PA was in the middle. The resulting overlay of co-processed were more similar to purple sweet potato starch. This was because the co-process composition in the optimum formula contained a higher concentration of purple sweet potato starch than Avicel PH 101. FT-IR test results showed that the formation of this co-process did not change the chemical structure of the substance, but only changed the physical properties of the excipient.

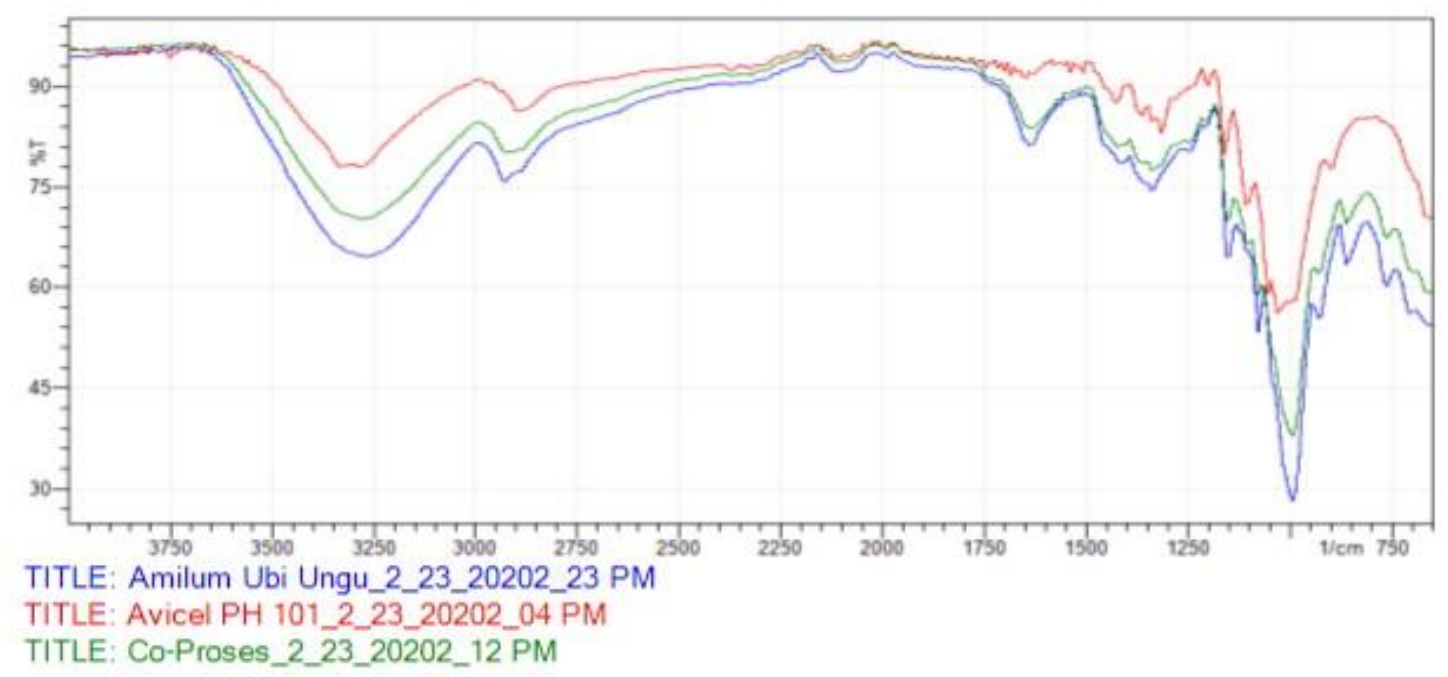

Figure 3. FT-IR Image from Purple Sweet Potato Starch; Avicel PH 101 and Co-processed PA
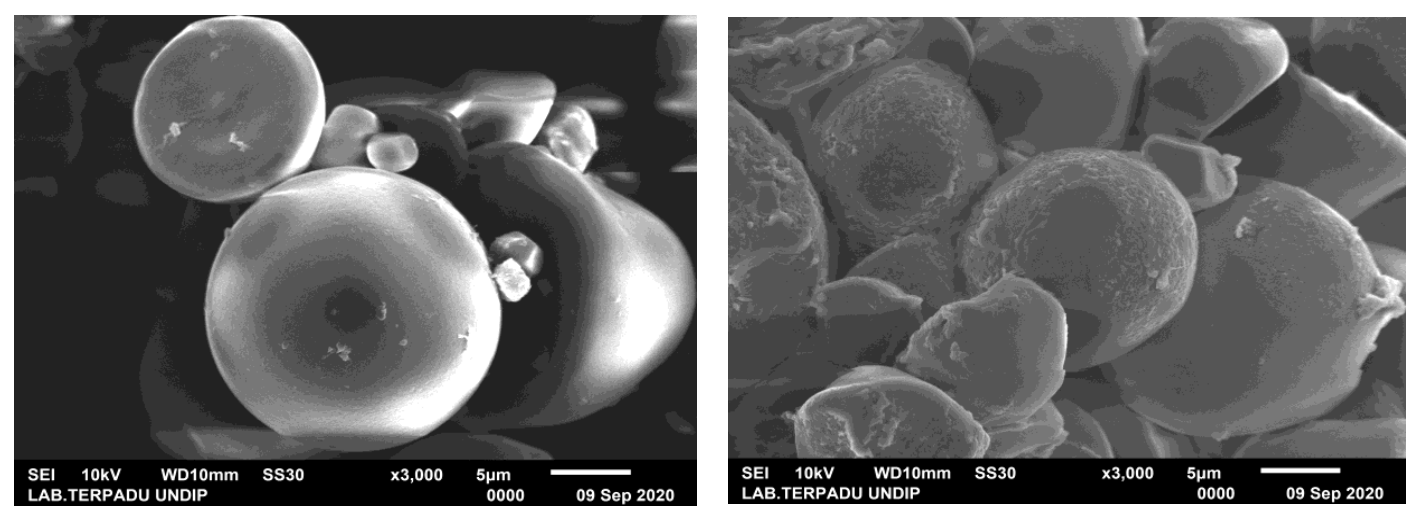

Figure 4. (A) SEM Image of Purple Sweet Potato Starch; (B) SEM Image of Co-processed Purple Sweet Potato Starch-Avicel PH 101 (PA)

Evaluation Scanning Electron Microscopy (SEM) aimed to see the surface morphology of particles or 3-dimensional particle shape and particle size through an image. There was a change in the particle shape of the purple sweet potato starch after co-processing. It was seen that there was a change in the surface of the purple sweet potato starch and the co-processed PA. Based on the SEM results, it could be seen that the co-processed PA morphology was the nucleation between starch paste with mixture of starch and avicel so that the grains became coarse but still spheris. 


\section{CONCLUSION}

The difference in concentration ratio in each co-process formula of purple sweet potato starch - Avicel PH 101 affected the physical properties of the co-process produced. The formula that gave the best co-processing properties was obtained at a concentration ratio of purple sweet potato starch and Avicel PH 101 of 62.493\%: 37.507\%. Co-processing of purple sweet potato starch with Avicel PH 101 has been shown that it can be improve the compresibility and flowability properties of purple sweet potato starch.

\section{References}

1. Anwar, E. Usaha Peningkatan Mutu Pati Singkong Dan Pembuatan Derivatnya sebagai Bahan Pendukung Dalam Industri Farmasi: Karakterisasi Pregelatinized Amylum. Badan Litbang Kesehatan. [Online] : http://digilib.litbang.depkes.go.id/go.PHp?id=jkpkbbpk-gdl-grey1999-effionora-132- pati. 2001.

2. Ditjen Farmalkes. Buletin Infarkes : Informasi Kefarmasian dan Alat Kesehatan Edisi II. Jakarta : Ditjen Farmalkes, 2016.

3. Hidranto, Firman. Solusi Ketergantungan Impor Bahan Baku Obat. [Online]: https://indonesia.go.id/narasi/indonesia-dalam-angka/ekonomi/solusi-ketergantungan- impor-bahanbaku-obat. 2020.

4. Hauschild, K., dan Picker, K. M. Evaluation of New Coprocessed Compound Based on Lactose and Maize Starch for Tablet Formulation, Pharm Sci Tech, 2004, 6 (2).

5. Gohel, M. C., dan Jogani, P.D. Investigation of direct compression characteristics of coprocessed lactosestarch using factorial design, Indian. J. Pharm Sci. 2003, 65 (1) : 31-38.

6. Voigt, R. Buku Pelajaran Teknologi Farmasi. Yogyakarta : Gadjah Mada University Press., 1994.

7. Health Department of the Republic of Indonesia. Indonesian Pharmacopeia $5^{\text {th }}$ Edition. Jakarta : Health Department of the Republic of Indonesia. 2015.

8. Hadisoewignyi, Lannie dan Fudholi, Ahmad. Sediaan Solida. Yogyakarta : Pustaka Pelajar, 2013.

9. Panić, V.V, Sanja I. Šešlija, Aleksandra R. Nešić2, Sava J. Veličković3. Adsorption of azo dyes on polymer materials Hemijska industrija, 2013, 67 (6) : 881-900.

10. Cantor, S., Augsburger L.L., Hoag, S.W. Pharmaceutical Dosage Forms: Tablets, Voilume 1: Unit Operations and Mechanical Properties Edition: 3rd Chapter 8Publisher : Informa Healthcare. 2008, pp : 271.

11. Yugatama, A., Maharani, L., Pratiwi, H., dan Ikaditya, L. Uji Karakteristik Mikrokristalin Selulosa dari Nata De-Soya Sebagai Eksepien Tablet. Farmasains. 2015, 2 (6): 269-274.

(C) 2020 by the authors. Submitted for possible open access publication under the terms and conditions of the Creative Commons Attribution (CC BY) license (http://creativecommons.org/licenses/by/4.0/). 